\title{
BEBERAPAMASALAHKRUSIAL SEPUTAR PERBURUHAN
}

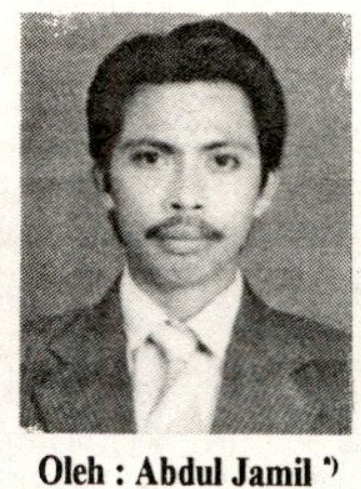

Secara struktural, pihak buruh adalah pihak yang tersubordinasi -- dalam menentukan segala hal. Posisi inilah yang banyak dimanfaatkan pihak-pihak tertentu untuk semakin merugikan dan mengalahkan

kaum buruh. Hal ini akhirnya bermuara pada belum terjaminnya kebebasan kaum buruh, sistem pengupahan yang kurang apresiatif, serta pengawasan dan perhatian pemerintah yang masih lemah. Uraian ekstensif dari berbagai masalah tersebut bisa disimak pada tulisan Abdul Jamil berikut.

\section{PENDAHULUAN}

Perburuan adalah tema yang menarik untuk diangkat dalam kajian ilmiah. Hal ini berkaitan dengan mencuatnya kasus-kasus perburuhan yang akhir-akhir ini mendapatkan perhatian secara husus.

Kasus-kasus perburuhan yang timbul tidak bisa lepas dari kondisi kebijakan pemerintah dalam upaya menuju industrialisasi; meminjam istilah Robertsen, dinamakan sebagai The Interventionist Developmental State yaitu negara yang melaksanakan perencanaan secara sistimatis untuk mengarah- kan transformasi struktural dari masyarakat agraris menuju kemasyarakat Industrialisasi. ${ }^{1)}$

Kebijakan pemerintah untuk menjadikan Indonesia sebagai Negara Industri yang mengakui peranan swasta dalam pembangunan, telah mendorong para investor memacu laju pertumbuhan industrialisasi di daerah-daerah.

Pertumbuhan industrialisasi di daerah tersebut ternyata banyak menimbulkan permasalahan perburuhan. Kasus-kasus perburuhan yang muncul selain disebabkan karena praktek prilaku majikan atau pengusaha yang

"Abdul Jamil, SH., adalah staf pengajar FH. UII. Aktif sebagai pengelola LKBH UII Yogyakarta.

1) Juni Thamrin; Upah, Tingkat Hidup dan Kondisi Kerja Buruh Industri, Manufaktur pada Masa Orde Baru, Makalah seminar sehari-hari Hak Asasi Manusia, LBH. Yogyakarta, 1993, hal.2. 
tidak memperhatikan hak-hak maupun penghargaan terhadap kesejahteraan buruh, misalnya: upah, tunjangan, jaminan sosial, pemutusan hubungan kerja dan lain sebagainya, juga karena posisi buruh masih sebagai alat produksi yang dipacu untuk mencapai keuntungan perusahaan setinggi-tingginya.

Dalam konflik-konflik buruh - majikan ada kecenderungan untuk menimpakan kesalahan pada buruh, sehingga penyelesaian yang ditempuh lebih banyak merugikan kaum buruh.

\section{EKSPLOITASI BURUH}

Suatu aktivitas perburuhan dapat dikatakan sebagai eksploitasi buruh apabila terjadi pertentangan dengan prinsip-prinsip perburuhan. Prinsip seorang buruh adalah "subyek" pelaku industri bukan sebagai "alat" produksi. Karena buruh berlaku sebagai subyek, maka mempunyai hak dan kewajiban seperti halnya seorang majikan/pengusaha.

Hak yang timbal balik - ini terlihat dari pegertian pasal 1601 a KUHPerdata. Yang dimaksud perjanjian kerja dalah suatu perjanjian dimana pihak yang satu (buruh) mengikatkan diri untuk bekerja pada pihak yang lain, (majikan) selama suatu waktu tertentu dengan menerima upah.

Dalam praktek, prinsip-prinsip perburuhan masih sering disimpangi karena beberapa sebab :

\section{Arti dan ruang lingkup Perburuhan}

Dalam kehidupan sehari-hari masih terdapat kerancuan istilah mengenai penyebutan pekerja, terutama dalam hubungan kerja pada perusahaan di luar Instansi Pemerintah. Penyebutannya ada yang menggunakan istilah karyawan, atau buruh, namun pada hakekatnya istilah tersebut mengandung arti yang sama, yaitu orang yang bekerja pada orang lain (Badan Hukum atau perorangan) dan mendapatkan upah sebagai imbalannya.

Dari istilah tersebut diatas, mempunyai kesan yang tidak menguntungkan, yaitu istilah buruh yang biasa digunakan bagi pekerja diperusahaan swasta murni, yang menampung banyak pekerja atau perseorangan yang mempunyai sifat pekerjaan yang ada hubungan timbal balik antara pekerja dan majikan.

Pengertian di atas dapat dilihat dari rumusan pasal 1 (1)a UU No. 22/1957, buruh adalah barang siapa bekerja pada majikan dengan menerima upah. Peraturan Pemerintah No. 8/1981 pasal 1 (c) menentukan bahwa buruh adalah tenaga kerja yang bekerja pada pengusaha dengan menerima upah. Demikian juga UU No 7/1981 Pasal 1 sub d, mengatakan buruh adalah tenaga kerja yang bekerja pada perusahaan dengan menerima upah.

Melihat rumusan di atas ruang gerak buruh/pekerja sangat luas, yaitu mulai Pembantu Rumah Tangga, pekerja Industri sampai Direktur Perusahaan, hal ini dapat terjadi karena ikatan perburuhan.

Dari rumusan pasal tersebut hubungan perburuhan harus memenuhi dua unsur pokok yaitu, pekerja dan majikan yang dimungkinkan perorangan atau badan usaha serta adanya upah sebagai imbalan prestasi yang dilakukan oleh buruh. Dengan demikian buruh berkewajiban melakukan pekerjaan di bawah perintah orang lain (majikan).

Dari pengertian tersebut apabila dilihat dari segi kewajiban buruh maka posisi buruh sangatlah tidak menguntungkan, itulah sebabnya buruh dalam posisi yang lemah karena dia di bawah perintah majikan.

\section{Kondisi sosial buruh}

Secara jujur kita sadari bersama 
bahwa kondisi sosial buruh di Indonesia masih terjadi ketidakseimbangan antara lapangan kerja dan calon tenaga kerja. Jumlah yang akan bekerja jauh lebih besar dibanding dengan lapangan kerja yang tersedia. Oleh karena itu wajar apabila terjadi kompetisi yang sangat ketat dalam mencari kerja.

Posisi tenaga kerja di Indonesia sampai dengan Repelita VI yang akan datang mengenai pasar kerja diperkirakan masih tetap tidak seimbang. Pertumbuhan angkatan kerja setiap tahun masih lebih besar dari pertumbuhan kesempatan kerja baru yang dapat dicipatakan, apalagi bila dibandingkan dengan kesempatan kerja disektor formal. Sebagai gambaran dalam Repelita V ini, angkatan kerja bertambah dengan 11,9 juta orang tetapi penyerapan tenaga kerja diperkirakan hanya 11,5 juta. Sektor formal sendiri hanya menyerap sekitar $30 \%$ angkatan kerja. Dengan demikian, sektor formal akan menyerap hanya sekitar 30\% dari pertambahan 11,5 juta kesempatan kerja baru dalam Repelita V. ${ }^{2)}$

Kondisi kesenjangan diantara buruh yang bersaing juga masih tajam. Misalnya buruh yang berpendidikan dasar, menengah, atas dan tinggi.

Dampak yang timbul dari kesenjangan tersebut sering dimanfaatkan oleh pihak majikan dalam sistim penerimaan dan pengupahan. Sehingga sering terjadi buruh yang berpendidikan tinggi masuk kwalifikasi buruh yang berpendidikan menengah atas dan lain sebagainya.

Hal ini terjadi karena buruh tidak mempunyai pilihan lain, mereka dihadapkan pada dua persoalan yaitu bekerja dengan gaji rendah, pekerjaan yang tidak sesuai dengan disiplin ilmu atau keahliannya atau tidak bekerja (menganggur).

Kenyataan yang terjadi buruh mengambil pilihan ia harus bekerja walaupun gaji rendah, pekerjaan yang tidak sesuai kemampuannya dan beberapa resiko lainnya yang timbul dari kondisi pekerjaan yang dilakukan.

Selanjutnya permasalahan yang muncul dari adanya praktek ekspoitasi buruh; antara lain;

\section{Pertama}

Kebebasan buruh, baik dalam membuat perjanjian, berserikat dan mogok.

Kebebasan buruh yang dimaksud adalah kebebasan dalam menentukan hak dan kewajiban dalam kerja, kebebasan dalam membuat perjanjian dengan majikan dan lain sebagainya yang menyangkut kepentingan buruh.

Kenyataan dalam praktek kebebasan seorang buruh dalam menentukan hak, misalnya upah masih terjadi ketidakseimbangan, karena dalam praktek yang menentukan besar kecilnya upah adalah majikan dengan harapan mengakumulasikan keuntungan yang lebih besar, dan buruh hanya tinggal menandatangani persetujuan (dalam perjanjian).

Dalam pembuatan perjanjian perburuhan pada umumnya lemahnya posisi buruh sering dimanfaatkan. Perjanjian yang dibuat antara buruh dan majikan sering dilakukan secara sepihak oleh majikan/pengusaha dalam bentuk baku. Kemudian jika ada pekerja yang ingin bekerja di perusahaan itu, harus terlebih dahulu diminta menyetujui dan menandatangani, perjanjian kerja baku tersebut sebagai

2) Dr. Payaman J. Simanjuntak, Posisi Tenaga Kerja dalam Hubungan Industrial, Makalah seminar ketenagakerjaan dan Pemogokan, diselenggarakan oleh ESPEKA BINA INDUSINDO, Jakarta tanggal 15 Januari 1992. 
perjanjian baku, biasanya membuat syaratsyarat exonoratie yang melindungi pengusaha dari akibat-akibat tertentu. ${ }^{3)}$

Dalam perjanjian di atas jelas hal tersebut merupakan suatu siasat majikan untuk menghindari kewajiban yang timbul dalam konsekwensi perjanjian.

Adalah suatu kewajaran jika dalam hubungan perjanjian antara pihak-pihak yang saling terikat di dalamnya terdapat hak dan kewajiban juga memuat kesepakatan antara keduanya, seperti rumusan pasal $1320 \mathrm{KUH}$ Perdata. Kewajiban buruh merupakan hak majikan dan hak buruh merupakan kewajiban majikan. ${ }^{4)}$

Adapun kewajiban buruh pada pokoknya antara lain; melakukan pekerjaan, mentaati tata tertib perusahaan, membayar denda dan ganti rugi serta bertindak sebagai buruh yang baik. Selain itu bagi buruh yang bertempat tinggal pada majikan, wajib mentaati tata tertib rumah tangga.

Sedangkan hal yang diterima oleh buruh sebagai mana yang diatur dalam UU, antara lain:

1. Pasal 1602 KUH Perdata, hak mendapatkan upah/gaji.

2. Pasal 3 UU No. 14/1969, hak atas pekerjaan dan penghasilan yang layak bagi kemanusiaan.

3. Pasal 4 UU No $14 / 1969$, hak bebas memilih dan pindah pekerjaan sesuai bakat dan minat kemampuannya.

4. Pasal 6 UU No $14 / 1969$, hak atas pembinaan keahlian kejuruan untuk memperoleh serta menambah keahlian dan ketrampilan
5. Pasal 9 UU No 14/1969, hak atas keselamatan, kesehatan serta perlakuan yang sesuai dengan martabat manusia dan umat Agama.

6. Pasal 11 UU No $14 / 1969$, hak mendirikan dan menjadi anggota perserikatan tenaga kerja.

7. Peraturan Pemerintah No. 21/1054, hak atas cuti dari pekerjaan.

Bentuk dari hak dan kewajiban tersebut bersifat kumulatif yang wajib mengikuti dalam perjanjian perburuhan sehingga tidak ada pihak yang diuntungkan atau dirugikan, akibat dari bentuk perjanjian perburuhan.

Kebebasan buruh untuk menentukan atau masuk dalam organisasi perserikatan buruh yang dapat melindungi terhadap penyaluran aspirasi dan kepentingan buruh. $\mathrm{Hal}$ ini jelas tidak mungkin dilakukan karena organisasi buruh sudah ditentukan dengan wadah tunggal Serikat Pekerja Seluruh Indonesia (SPSI) hasil bentukan dan yang dianggap sah oleh Pemerintah.

SPSI dibentuk dengan harapan sebagai institusi yang memperjuangkan nasib serta menampung dan menyelesaikan permasalahan perburuhan. Sehingga organisasi ini harus ada pada setiap perusahaan dan bersifat independensi. Namun kenyataan dalam kasus dilapangan peran SPSI kurang berfungsi dalam memperjuangkan hak-hak buruh. Keadaan seperti ini wajar karena pembentukan SPSI hanya sebagai formalitas persyaratan perusahaan.

Hak-hak buruh lain yang hampir tidak pernah dipergunakan yaitu hak mogok

3) Darwan Print, SH. Hukum Ketenagakerjaan Indonesia, Citra Aditya Bakti, Bandung, 1994, hal. 68.

') FX. Djumialdji, SH., Perjanjian Kerja, Bumi Aksara, Jakarta, 1992, hal. 79. 
walaupun diatur dalam Undang-Undang pada hakekatnya buruh diperbolehkan mogok apabila prosedur yang ditempuh untuk memperjuangkan hak-haknya sudah maksimal dan tidak mendapatkan tanggapan. Akan tetapi hak mogok bagi buruh sekarang ini sudah berkembang tidak lagi menjadi masalah yang "legal" namun lebih cenderung menjadi masalah politik. Hal ini terbukti sebelum buruh menggunakan hak mogok harus memberitahu kepada Pemerintah, dengan demikian Pemerintah dapat memantau dan mencegah hak buruh tersebut.

Keterlibatan aparat keamanan dalam. menangani kasus mogok dan unjuk rasa buruh yang kita saksikan akhir-akhir ini adalah merupakan dampak negatif yang muncul.dari justifikasi aparat tersebut. Kondisi seperti ini jelas merugikan buruh, karena mogok bagi buruh adalah hak yang diperbolehkan dan merupakan "bergaining power" untuk mengimbangi posisi buruh dengan majikan/ pengusaha. Sehingga jalan itulah yang dapat dilakukan oleh buruh untuk menekan kesewenang-wenangan majikan dan jalan untuk menuntut hak buruh.

Dari gambaran tersebut posisi buruh benar-benar tersudut, karena yang dihadapi tidak saja tekanan majikan, tetapi juga dari pemerintah. Pemogokan buruh dianggap sebagai ancaman terhadap stabilitas nasional.

\section{Kedua; Upah buruh masih rendah.}

Kasus-kasus pemogokan dan unjuk rasa yang selalu meningkat dari tahun ke tahun, misalnya saja pada tahun 1991 jumlah kasus pemogokan 114 yang disebakan karena sengketa upah 76 kasus, tahun 1992 jumlah total pemogokan 177 kasus yang disebabkan karena sengketa upah antara majikan dengan buruh mencapai 117 kasus. Bahkan yang akhir-akhir ini sering mencuat misalnya di Medan, Jakarta; Semarang, Solo dan lain sebagainya, masih banyak diakibatkan oleh tuntutan upah minimum, jaminan sosial, kesejahteraan buruh dan lain sebagainya.

Sampai sekarang persoalan upah memang belum terpecahkan, bahkan kondisi upah buruh kita masih sangat murah apabila dibandingkan dengan negara-negara Asia lainnya. Kondisi semacam ini karena dipengaruhi beberapa sebab :

1) Adanya perbedaan pandangan fungsi upah, antara pengusaha. buruh dan pemerintah. Pengusaha memandang upah sebagai komponen biaya produksi dari barang dan jasa yang dihasilkan.

Sedang buruh memandang upah sebagai komponen pokok penghasilan yang tersedia baginya untuk menjamin kelangsungan hidupnya beserta keluarganya, untuk meningkatkan kehidupan ditengah-tengah lingkungannya serta mempertahankan martabatnya sebagai warga yang baik. Oleh sebab itu segala upaya harus dilakukan agar upah selalu meningkat. Pemerintah memandang upah sebagai suatu standar hidup masyarakat, oleh karena itu rumusan upah harus dapat menciptakan iklim usaha dan sosial yang baik agar dengan demikian kepentingan masyarakat bisa dipadukan. ${ }^{5)}$

2). Masih banyak pengusaha yang cenderung menekan upah dengan harapan dapat

5) Widanti, SH. CN., Implementasi Undang-Undang Perburuhan, Permasalahan dan Penyelesaiannya, makalah cramah dan dialog meningkatkan etos keja pekerja wanita dengan memasyarakatkan Jamsostek dan Undang-Undang Perburuhan tentang buruh wanita. Diselenggarakan oleh Yayasan Pengembangan Sumber Daya Wanita dan anak Yatim, Solo, tanggal 27 November 1993. 
mengakomulasikan keuntungan yang lebih besar. Sikap dan praktek pengusaha menekan upah, membuka peluang untuk meningkatkan perselisihan hubungan industrial. Sekarang ini masih banyak pengusaha yang mempunyai ilusi bahwa dengan menekan upah, pengusaha akan mendapat keuntungan yang lebih besar. Padahal menurut teori Ekonomi, teori menegement dan teori hubungan industrial dapat disimpulkan bahwa dengan menekan upah dibawah tingkat tertentu secara langsung dan tidak langsung justru akan menimbulkan kerugian kepada pengusaha. ${ }^{6)}$

Ketiga; Sistim pengawasan ketenagakerjaan masih lemah.

Dalam praktek sistem pengawasan terhadap buruh (tenaga kerja) yang dilakukan oleh Pemerintah masih lemah. Hal ini disebabkan adanya beberapa kendala: 1) Pihak perusahaan mungkin tidak melaporkan diri pada pemerintah, 2) pihak buruh sendiri juga tidak terikat dalam wadah organisasi Buruh (SPSI), 3) Pihak buruh tidak mengetahui pengaduan yang berkaitan dengan perlindungan buruh.

\section{UPAYA PENEGAKAN HAK}

Upaya yang dapat dilakukan bagi buruh untuk menuntut hak dalam praktek dapat dilakukan apabila terjadi perselisihan antara buruh dan majikan. Karena dalam perselisihan perburuhän (perselisihan industri) ada dua hal yang sering muncul, yaitu :

1) Perselisihan hak, yaitu perselisihan industrial yang bersumber dari hal-hal yang sudah normatif/sudah diatur dalam peraturan perundang-undangan ketenagakerjaan, peraturan perusahaan, kesepakatan kerja bersama atau suatu perjanjian.

2). Perselisihan kepentingan, yaitu perselisihan yang bersumber dari hal-hal yang belum diatur secara normatif, baik dalam peraturan perundangan, peraturan perusahaan, kesepatakan kerja bersama atau perjanjian."

Dari rumusan tersebut obyek sengketa yang dapat diperjuangkan bagi buruh bermuara pada dua persoalan, yaitu hak dan kepentingan yang melekat pada dua kepentingan, yaitu buruh dan majikan.

Didalam praktek penanganan perselisihan perburuhan banyak dipengaruhi oleh $\cdot$ kekuatan bergaining. Sehingga kalau penyelesaian itu diupayakan oleh buruh yang bersangkutan, ia sering dihadapkan pada persoalan kalasik, yaitu tekanan-tekanan, ditakut-takuti atau janji-janji manis dari majikan dan lain sebagainya. Dan biasanya buruh diarahkan untuk membuat surat pernyataan pengunduran diri.

Menyelesaikan dengan jalan pengunduran diri dari buruh adalah sering dilakukan oleh majikan, sebab jalan ini paling menguntungkan dan aman bagi majikan. Karena ia tidak terbebani kewajiban-kewajiban akibat perselisihan tersebut.

Dari pengalaman praktek, apabila buruh mengalami sengketa perselisihan dan ia tidak mau menandatangi pernyataan pengunduran diri kemudian ia menggunakan jasa perorangan atau lembaga yang mempunyai "otorias" bargaining sering berhasil dalam mengupayakan hak-hak buruh yang dilanggar.

9) Dr. Payaman J. Simanjuntak, op. cit., hal. 5.

${ }^{7}$ FF. Fardinandus, SE., Pencegahan dan Penyelesaian Industrial, Makalah seminar Nasional perlindungan hukum bagi kaum buruh. Fakultas Hukum Universitas Katholik Atmajaya, Jakarta, tanggal 27 Juli 1994. 
Dengan demikian dari pengalaman praktek, pengupayahan hak buruh ditentukan oleh dua unsur, 1). Kesadaran pihak buruh itu sendiri untuk meminta bantuan jasa pihak lain. 2). Jasa pihak lain yang mempunyai "otoritas".

Jalan yang demikian ini dapat dipahami karena posisi buruh di Indonesia masih dalam posisi yang lemah, tidak seimbang antara buruh dan majikan.

\section{DAFTAR PUSTAKA}

Danu Rudiono, Keterlibatan Aparat Koersif Dalam Kasus perburuhan dan realitas kekuatan tawar menawar. "buruh", Makalah Seminar, Mengenai Hari-hari hak azazi Manusia diselenggarakan oleh yayasa Lapera Indonesia dan LBH Yogyakarta, tanggal 9 Desember 1993.

Darwan Print, SH, Hukum Ketenagakerjaan Indonesia, Aditia Bakti, Bandung 1994.

F.F Ferdenandus SE. Pencegahan dan penyelesaian perselisihan Industrial, makalah seminar perlindungan. Hukum bagi kaum Buruh, diselenggarakan oleh Fakultas Hukum Universitas Katholik Admajaya Jakarta, tanggal 27 Juli 1994.

FX. Djumialdji, SH. Perjanjian kerja, Bumi Aksara, Jakarta, 1992.

Juni Thamrin, Upah, Tingkat Kehidupan dan Kondisi Kerja Buruh Indonesia manufakture pada masa Orde Baru, Makalah seminar mengenai hari Hak-hak Azasi Manusia, diselenggarakan oleh Yayasan Lapera Indonesia.
Payaman J. Simanjuntak, DR. Posisi Tenaga Kerja dalam hubungan Industrial, Makalah seminar ketenagakerjaan dan pemogokan, diselenggarakan oleh ESPEKA BINA INDOSINDO, Jakarta tanggal 15 Januari 1992.

Widanti, SH.CN, Implementasi UndangUndang Perburuhan permasalan dan penyelesaiannya; Makalah ceramah dan Dialog tentang peningkatan Etos Kerja Wanita dengan memasyarakatkan Jamsostek dan Undang-undang Perburuhan tentang buruh Wanita, diselenggarakan oleh Yayasan Pengembangan Sumber Daya Wanita dan Anak Yatim, tanggal 27 Nopember 1993. 